\title{
Mateusz Królikowski
}

Uniwersytet Wrocławski

e-mail: mateusz.krolikowski@uwr.edu.pl

ORCID: 0000-0002-1457-4860

\section{MOŻLIWOŚĆ ZASTOSOWANIA PRZEPISÓW \\ O WADACH OŚWIADCZENIA WOLI DO UMÓW \\ ZAWARTYCH W TRYBIE ZAMÓWIEŃ PUBLICZNYCH}

\author{
APPLICABILITY OF THE PROVISIONS \\ OF POLISH CIVIL CODE ON DEFECTS \\ IN DECLARATION OF INTENT TO THE CONTRACTS \\ CONCLUDED IN ACCORDANCE \\ WITH PUBLIC PROCUREMENT RULES
}

DOI: $10.15611 / \mathrm{pn} .2018 .540 .16$

\begin{abstract}
Streszczenie: Artykuł dotyczy możliwości zastosowania przepisów o wadach oświadczenia woli do umów zawieranych w trybie zamówień publicznych. Autor omawia problematykę czynności prawnej (umowy) dokonywanej z wykorzystaniem mechanizmów zawierających elementy administracyjne. Stawia pytanie o skuteczność czynności prawnej dokonanej pod wpływem wady oświadczenia woli. Przyjmuje, że podstawy wadliwości czynności prawnych przewidziane w kodeksie cywilnym mogą mieć również niekiedy zastosowanie do umów zawartych w trybie zamówień publicznych. Omawia poszczególne wady (w tym między innymi błąd), konfrontując przepisy o wadach oświadczenia woli z regulacjami o charakterze administracyjnym. Artykuł dotyka również kwestii praktycznej doniosłości regulacji wad oświadczenia woli w zakresie umów zawieranych w ramach zamówień publicznych.
\end{abstract}

Słowa kluczowe: wady oświadczenia woli, błąd, zamówienia publiczne.

Summary: The article concerns the issue of applying the provisions of Polish Civil Code on defects in declaration of intent to the contracts concluded in accordance with public procurement rules. The author discusses the problem of legal act (a contract) concluded using legal mechanisms partially based on administrative law. He poses a question about the validity of such acts concluded under the influence of defects in declaration of intent. The author assumes, that some grounds for invalidity of legal acts stated in Civil Code may apply also to the contracts signed in the public procurement procedure. He discusses particular defects in declaration of intent (for instance a mistake or a fraud), confronting the provisions of the Civil Code with administrative regulations. Moreover, the article deals with issue of practical significance of provisions on defects in declaration of intent regarding contracts concluded in accordance with public procurement rules.

Keywords: defects in declaration of intent, mistake, public procurement. 


\section{Wstęp}

Ustawa z dnia 29 stycznia 2004 r. Prawo zamówień publicznych ${ }^{1}$ (dalej - p.z.p.) reguluje tryb udzielania zamówień publicznych, służących realizacji potrzeb o charakterze powszechnym, a także związanych $\mathrm{z}$ wydatkowaniem środków publicznych. Ta regulacja o istotnym wymiarze publicznoprawnym nasycona jest jednak również elementami prywatnoprawnymi, jako że udzielenie zamówienia następuje ostatecznie w drodze czynności prawnej (umowy), a nie decyzji administracyjnej czy innej czynności o charakterze władczym. Strony zawartej umowy występują na równorzędnych pozycjach podmiotów prawa cywilnego (brak tu elementu podporządkowania władczego $)^{2}$. Sam zaś tryb zawierania umowy, będący zasadniczym przedmiotem regulacji ustawy, stanowi modyfikację rozwiązań cywilnoprawnych, jako że przetarg i aukcja są jednymi z podstawowych sposobów zawierania umów unormowanych w przepisach Kodeksu cywilnego. W tym kontekście jako zasadne i istotne jawi się pytanie o zakres i możliwość stosowania przepisów prawa cywilnego do umów zawieranych w trybie zamówień publicznych, jak również dalsza kwestia wykładni tych przepisów, uwzględniającej publiczny element zawieranych umów.

Problematyka autonomii woli osoby dokonującej czynności prawnej (składającej oświadczenie woli) stanowi istotny przedmiot rozważań doktryny prawa cywilnego. Współczesna cywilistyka w znacznym zakresie postrzega te kwestie przez pryzmat pewnego konfliktu wartości, gdzie z jednej strony zachodzi potrzeba ochrony autonomii i wolności jednostki, a z drugiej - należy uwzględnić uzasadnione oczekiwania i zaufanie innych uczestników obrotu prawnego. Normy regulujące wady oświadczenia woli można rozpatrywać i opisywać w kontekście próby wyważenia pewnego kompromisu w zakresie realizacji tych przeciwstawnych wartości. W przypadku umów zawieranych w trybie zamówień publicznych pojawia się jednak jeszcze jeden element, gdyż realizacja takich zamówień ma służyć, chociażby pośrednio, realizacji pewnych celów powszechnych, a nie jedynie zaspokojeniu osobistych czy materialnych potrzeb stron umowy. Element ten może niewątpliwie wpływać na ocenę roli przepisów o wadach oświadczenia woli w kontekście problematyki zamówień publicznych.

\section{Możliwość stosowania regulacji wad oświadczenia woli do umów zawieranych $w$ trybie zamówień publicznych}

\subsection{Czy stosujemy przepisy kodeksu cywilnego?}

Podstawowe pytanie, na które należy odpowiedzieć na wstępie prowadzonych rozważań, dotyczy możliwości zastosowania przepisów o wadach oświadczenia woli do umów zawieranych w trybie zamówień publicznych. Stosowanie tych

${ }^{1}$ Tekst jednolity Dz.U. 2018, poz. 1986 ze zm.

${ }^{2}$ Zob. M. Jaworska, [w:] Prawo zamówień publicznych. Komentarz, red. M. Jaworska, Warszawa 2018, s. 154. 
przepisów niewątpliwie obniża, w pewnym zakresie, pewność obrotu prawnego, tak istotną z punktu widzenia czynności prawnych, których celem jest lub może być realizacja pewnych potrzeb o charakterze powszechnym. Wady oświadczenia woli są regulowane przepisami kodeksu cywilnego, natomiast prawo zamówień publicznych to domena regulacji szczególnej, modyfikującej ogólne zasady dotyczące sposobu zawierania umowy. Co więcej, artykuł 146 p.z.p. wprowadza szczegółową regulację podstaw do unieważnienia umów zawartych w trybie zamówień publicznych.

Należy mieć jednak na uwadze, że zgodnie z art. 14 ust. 1 p.z.p. do czynności podejmowanych przez zamawiającego i wykonawców w postępowaniu o udzielenie zamówienia stosuje się - w razie braku uregulowań szczególnych - przepisy Kodeksu cywilnego. W myśl art. 139 ust. 1 p.z.p. do umów zawartych w sprawach zamówień publicznych zastosowanie także znajdują normy Kodeksu cywilnego (również w przypadku braku odmiennych rozwiązań szczegółowych). Na podstawie wykładni przywołanych przepisów przyjmuje się, że umowy zawierane w trybie zamówień publicznych są czynnościami cywilnoprawnymi, których charakter wyznaczają normy prywatnoprawne, a nie administracyjne. Przepisy Kodeksu cywilnego obejmują wiele kwestii związanych z zawarciem umowy, jej treścią oraz formą i w tym zakresie znaczenie mają chociażby unormowania dotyczące oferty (art. 66 k.c.), pełnomocnictw (art. 98 i n. k.c.), formy czynności prawnych (art. 73 i n. k.c.) czy zasady swobody umów (art. $353^{1}$ k.c.) $)^{3}$.

Umowa zawarta w trybie zamówień publicznych może również okazać się nieważna na podstawie przepisów kodeksu cywilnego - przede wszystkim podstawą jej nieważności może być sprzeczność z przepisami prawnymi bezwzględnie wiążącymi lub zasadami współżycia społecznego, o czym stanowi art. 58 k.c. ${ }^{4}$ Podstawy unieważnienia umowy przewidziane w art. 146 ust. 1 i 6 p.z.p. dotyczą naruszeń o charakterze proceduralnym, niedopełnienia obowiązków przewidzianych dla tego szczególnego trybu dokonywania czynności prawnej (np. niezamieszczenie wymaganego ogłoszenia w Biuletynie Zamówień Publicznych czy zawarcie umowy przed upływem stosownych terminów ustawowych, co uniemożliwiło uwzględnienie odwołania wniesionego przez wykonawcę). Nie dotykają one zaś kwestii związanych z wymogami konstrukcyjnymi decydującymi o istnieniu i skuteczności czynności prawnej czy treścią składanych oświadczeń woli.

Na możliwość stosowania przepisów o błędzie jako wadzie oświadczenia woli w toku prowadzonego postępowania u udzielenie zamówienia publicznego zwróciła uwagę Krajowa Izba Odwoławcza w wyroku z dnia 28 listopada 2011 r. ${ }^{5}$ (sygn. akt KIO 2446/11), przyjmując, że ,zamawiający, ilekroć uzna, że jego oświadczenie

${ }^{3}$ Por. P. Granecki, Prawo zamówień publicznych. Komentarz, Warszawa 2016, s. 230.

${ }^{4}$ Stanowisko to potwierdza opinia zamieszczona na rządowej stronie internetowej Urzędu Zamówień Publicznych: https://www.uzp.gov.pl/baza-wiedzy/interpretacja-przepisow/opinie-archiwalne/ uniewaznienie-umowy-w-sprawie-zamowienia-publicznego.

${ }^{5}$ Lex nr 1102619. 
o wyborze najkorzystniejszej oferty dotknięte było błędem wynikającym z wadliwej oceny oferty lub dokumentów złożonych wraz z ofertą, może uchylić się od jego skutku - zawarcia umowy w sprawie zamówienia publicznego z danym wykonawcą - przez złożenie stosownego oświadczenia (art. 84 i 88 k.c. w związku z art. 14 p.z.p.)". Warto w tym miejscu zwrócić również uwagę na uzasadnienie wyroku Zespołu Arbitrów przy Urzędzie Zamówień Publicznych z dnia 19 stycznia 2005 r.

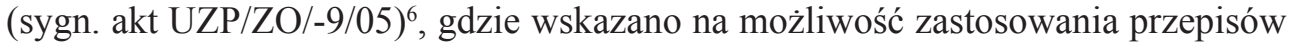
o błędzie do czynności zamawiającego w przedmiocie wykluczenia jednego z wykonawców z prowadzonego postępowania.

W konsekwencji nie powinno budzić wątpliwości, że przepisy o wadach oświadczenia woli powinny znaleźć zastosowanie również do samej umowy zawartej w wyniku przeprowadzonego postępowania. Wady te mogą wystąpić zarówno po stronie zamawiającego, jak i po stronie wybranego wykonawcy, a skutkować będą bezwzględną nieważnością umowy bądź jej nieważnością względną (możliwością uchylenia się przez stronę od skutków złożonego oświadczenia woli). W tym ostatnim wypadku pozbawienie umowy skuteczności będzie zależeć od aktywności samej strony, która może wykonać przysługujące jej uprawnienie kształtujące przez złożenie stosownego oświadczenia kontrahentowi. Warto w tym miejscu odnotować wyrok Sądu Najwyższego z dnia 10 kwietnia 2003 r. (sygn. akt III CKN 1320/00)ㄱ, w którym wskazano na cywilnoprawny charakter podobnego uprawnienia o charakterze kształtującym w postaci ustawowego prawa odstąpienia od umowy, z którego skorzystać może także strona umowy zawartej w trybie zamówień publicznych.

\subsection{Interpretacja norm cywilnoprawnych}

Kolejny problem dotyczy sposobu stosowania przepisów o wadach oświadczenia woli, czyli wpływu regulacji ustawy Prawo zamówień publicznych na interpretację przepisów kodeksowych. W ocenie autora element publiczny przyświecający regulacji szczegółowej prawa zamówień publicznych powinien wywierać wpływ na wykładnię tych przepisów. Umowy zawartej w takim trybie nie można postrzegać wyłącznie w kategoriach rynkowej walki dwóch podmiotów dążących do realizacji swoich indywidualistycznych celów czy interesów ekonomicznych. Nie oznacza to, że zamawiający powinien mieć jakieś dodatkowe uprawnienia czy przywileje w zakresie korzystania z kompetencji prywatnoprawnych. Uznać jednak należy, że w przypadku powoływania się przez wykonawcę na wadę oświadczenia woli wykładnia stosownych przesłanek, od których uzależnione jest istnienie wady, powinna mieć ścisły charakter i nie stwarzać szerokich podstaw do kwestionowania dokonanej czynności. Uwagi te należy odnieść jednak przede wszystkim do błędu (art. 84 k.c.), gdyż pozostałe wady wiążą się z poważnym ograniczeniem autonomii woli

\footnotetext{
${ }^{6}$ Lex nr 171871.

${ }^{7}$ OSNC 2004, nr 7-8, poz. 112, Lex nr 81627.
} 
jednostki związanym z cechami osobowymi strony (art. 82 k.c.), względnie z nieetycznym i bezprawnym działaniem kontrahenta (art. 86, art. 87 k.c.). Tymczasem kwestia spełnienia przesłanek błędu jako wady oświadczenia woli może być w wielu wypadkach dyskusyjna i w takich sytuacjach szczególnych nie ma podstaw do nadmiernie życzliwego traktowania strony zawierającej umowę w trybie zamówień publicznych. Za tezą tą przemawia również sam sformalizowany charakter postępowania, co niewątpliwie sprzyja refleksji, przygotowaniu treści oferty oraz wykrywaniu i eliminacji różnego rodzaju błędów mogących wystąpić w fazie zawierania kontraktu ${ }^{8}$.

Przy okazji warto rozważyć, czy strony nie mogą z góry - w treści zawieranej umowy - wyłączyć możliwości powołania się przez nie w przyszłości na wadę oświadczenia woli. Zgodnie z przeważającym stanowiskiem doktryny takie postanowienia umowne nie byłyby skuteczne, gdyż przepisy o wadach oświadczenia woli mają charakter bezwzględnie wiążący9. I jakkolwiek ustawodawca wprost nie wyłączył możliwości modyfikowania tych przepisów, to przyznać należy, że za bezwzględnie wiążącym charakterem wskazanych norm przemawia ich funkcja w postaci ochrony autonomii woli uczestników obrotu cywilnoprawnego. W ocenie autora ta ogólna teza nie musi mieć jednak zastosowania do błędu jako wady oświadczenia woli (art. 84 k.c.), o ile strony wprost w umowie wskażą dobitnie na ewentualne niejasności dotyczące okoliczności istniejących w chwili zawierania kontraktu i wyłączą możliwość powoływania się na nie w przyszłości. W ten sposób strony mogą niejako ustalić, że jedna z nich ponosi ryzyko tego, że określona okoliczność ma niekorzystny dla niej kształt ${ }^{10}$.

${ }^{8}$ Podobny postulat dotyczący ścisłej wykładni norm cywilnoprawnych można odnieść do interpretacji oświadczeń woli składanych przez strony. Interpretacja taka poprzedza ocenę co do zaistnienia ewentualnej wady oświadczenia woli. Szerzej na ten temat zob. M. Królikowski, Błąd jako wada oświadczenia woli strony umowy, Warszawa 2014, s. 22-24.

${ }^{9}$ Por. S. Rudnicki, [w:] S. Dmowski, S. Rudnicki, Komentarz do kodeksu cywilnego. Księga pierwsza. Część ogólna, Warszawa 2009, s. 411; J. Strzebinczyk, [w:] Kodeks cywilny. Komentarz, red. E. Gniewek, P. Machnikowski, Warszawa 2014, s. 226.

${ }^{10}$ Mowa w tym miejscu o okolicznościach już istniejących w chwili zawierania umowy, a jednak niejasnych, gdyż tylko do takich faktów możemy odnosić regulację błędu jako wady oświadczenia woli. W przypadku okoliczności przyszłych (zmian w zakresie obiektywnej rzeczywistości) powstanie odmienny problem możliwości zastosowania klauzuli rebus sic stantibus (art. $357^{1}$ k.c.). Należy w tym miejscu zasygnalizować, że przeważa zapatrywanie, zgodnie z którym regulacja art. $357^{1}$ k.c. ma charakter względnie wiążący, a zatem strony mogą z góry ustalić, że umowa będzie wykonywana zgodnie z jej pierwotnym kształtem, względnie mogą posłużyć się umowną klauzulą adaptacyjną. Por. A. Brzozowski, [w:] System prawa prywatnego. Tom 6. Prawo zobowiazań-część ogólna, red. A. Brzozowski, Warszawa 2018, s. 1316-1317; P. Machnikowski, [w:] Kodeks cywilny. Komentarz, red. E. Gniewek, P. Machnikowski, Warszawa 2017, s. 658. 


\section{Katalog wad oświadczenia woli w kontekście prawa zamówień publicznych}

\subsection{Uwagi wstępne}

Przepisy o wadach oświadczenia woli znajdują się w części ogólnej kodeksu cywilnego (art. 84-88 k.c.) i obejmują następujące wadliwości: brak świadomości albo swobody przy powzięciu decyzji i wyrażeniu woli, pozorność, błąd, groźbę oraz podstęp. Rozwiązania szczegółowe można odnaleźć w prawie spadkowym oraz w zakresie regulacji ugody. Te ostatnie unormowania szczególne nie będą mieć jednak istotnej doniosłości z punktu widzenia omawianej problematyki, a zatem można pominąc ich prezentację ${ }^{11}$. Pewne wątpliwości dotyczą wyzysku, gdyż część doktryny traktuje wskazane unormowanie jako wadę oświadczenia woli. Przeważa jednak zapatrywanie, zgodnie z którym przepisy o wyzysku nie regulują wady oświadczenia woli, lecz dotyczą przede wszystkim treści czynności prawnej i stanowią ograniczenie gwarantowanej prawem cywilnym zasady swobody umów ${ }^{12}$.

Przepisy kodeksu cywilnego nie wprowadzają odrębnej regulacji wad oświadczenia woli dla umów oraz innych czynności prawnych (czynności jednostronnych, uchwał). Niemniej jednak zastosowanie tych przepisów do umów będzie charakteryzować się określonymi odmiennościami. I tak regulacja pozorności dotyczy jedynie sytuacji, w której oświadczenie woli jest składane oznaczonemu adresatowi, a zatem regulacja ta będzie mieć znaczenie przede wszystkim w stosunkach umownych. Również w przypadku błędu ustawodawca wprowadza dodatkowe, szczególne przesłanki, które podlegają weryfikacji w przypadku oświadczeń woli składanych innej osobie. Dodać należy, że w relacjach prywatnoprawnych umowa jest podstawowym źródłem stosunków o charakterze zobowiązaniowym.

\subsection{Brak świadomości albo swobody}

Oświadczenie woli jest nieważne, jeżeli w chwili jego składania strona znajdowała się w stanie wyłączającym świadomość albo swobodę (na skutek choroby psychicznej, niedorozwoju umysłowego czy innego, chociażby nawet przemijającego, zaburzenia czynności psychicznych). Dla uznania, że wada wystąpiła, niewystarczające jest ograniczenie świadomości czy swobody. Bez znaczenia jest natomiast, jaka była przyczyna stanu, w którym strona była pozbawiona możliwości działania, jak również trwałość tego stanu, o ile zaburzenia występowały w dacie składania

${ }^{11}$ Jeśli chodzi o ugodę, to abstrahując od możliwości jej zawarcia w ramach zobowiązania powstałego na skutek umowy podpisanej w trybie zamówień publicznych, należy zauważyć, że kwestia ta dotyczy nie samej umowy, lecz późniejszego etapu związanego z jej wykonywaniem (bądź niewykonywaniem).

12 Por. P. Machnikowski, Swoboda umów wedlug art. $353^{I}$ KC. Konstrukcja prawna, Warszawa 2005, s. 198 oraz przywoływana tam literatura. 
oświadczenia woli. Wystąpienie opisanej wady w trakcie sformalizowanej procedury zamówień publicznych jest, jak się wydaje, mało prawdopodobne, jakkolwiek nie można takiej sytuacji wykluczyć, biorąc pod uwagę, że niektóre zaburzenia psychiczne mogą być niedostrzegalne dla otoczenia (szczególnie dla osób niepozostających w bliskich relacjach ze stroną).

Pewne wątpliwości mogą wystąpić, gdy zaburzenia psychiczne mają charakter przemijający, szczególnie że postępowanie o udzielenie zamówienia publicznego jest rozciągnięte w czasie. W tym kontekście wskazać można, iż wadą (nieważnością) może być dotknięta zarówno sama oferta złożona w toku postępowania, jak również późniejsze oświadczenie woli wykonawcy wybranego w drodze przetargu (czy innego postępowania) w przedmiocie zawarcia umowy. Problematyczna może okazać się również sytuacja, w której oświadczenie woli jest składane w toku komunikacji pośredniej (szczególnie w drodze tradycyjnej korespondencji pocztowej). W takim wypadku powstaje pytanie, czy istnienie wady powinniśmy weryfikować w odniesieniu do chwili nadania takiego oświadczenia, czy też na moment, gdy dociera ono do adresata tak, że ten może zapoznać się z jego treścią. Dosłowne odczytanie art. 61 k.c. nakazywałoby przyjąć, iż znaczenie ma ten drugi moment, jakkolwiek taka interpretacja pozostawałaby w sprzeczności ze specyfiką omawianej wady (chodzi wszak o wyeliminowanie wpływu wady na działania podejmowane przez stronę). W związku z tym uznać należy, że znaczenie ma chwila nadania oświadczenia. Wypada dodać, że wskazany problem ma mniejsze znaczenie w przypadku komunikacji elektronicznej, w wypadku której okres pomiędzy wysłaniem oświadczenia a jego dojściem do środka komunikacji elektronicznej odbiorcy jest zdecydowanie krótszy. W tym kontekście wskazać należy na rosnącą rolę komunikacji elektronicznej w prawie zamówień publicznych ${ }^{13}$, co niewątpliwie może przyczynić się do eliminacji sygnalizowanych trudności.

\subsection{Pozorność}

W przypadku pozorności występuje rozdźwięk pomiędzy uzewnętrznioną wolą a nieujawnionymi szerszemu otoczeniu rzeczywistymi zamiarami strony, które są jednak znane i aprobowane przez jej kontrahenta. W rachubę wchodzi zarówno sytuacja, w której strony w ogóle nie chcą, żeby zawarta umowa wywierała jakiekolwiek skutki prawne, jak również taka, gdy strony co prawda chcą skutecznie zawrzeć umowę, jednakże o treści odmiennej niż ta ujawniona zewnętrznemu otoczeniu. Zgodnie z przepisami Kodeksu cywilnego w takim wypadku uzewnętrznione oświadczenie woli jest nieważne, natomiast znaczenie prawne ma wewnętrznie uzgodnione przez strony porozumienie. Pamiętać należy jednak o tym, że ważność oświadczenia oceniana jest według właściwości tej rzeczywiście dokonywanej czynności (art. $83 \S 1$ in fine k.c.).

\footnotetext{
${ }^{13}$ https://www.uzp.gov.pl/e-zamowienia/elektronizacja-zamowien-publicznych.
} 
Odnosząc powyższe uwagi dotyczące pozorności do umów zawieranych w toku zamówień publicznych, można wyobrazić sobie sytuację, w której treść umowy ustalona w toku przetargu odbiega od faktycznych ustaleń pomiędzy stronami (zamawiającym a wykonawcą). Takie działanie może stanowić remedium pozwalające na faktyczne wyeliminowanie procedury przetargowej, jak też może być przejawem nielegalnego wydatkowania środków publicznych. Nie wchodząc jednak w szczegóły dotyczące motywacji oraz dalszych intencji stron, należy uznać, że takie umowy są bezwzględnie nieważne, co dotyczy nie tylko oświadczeń pozornych, lecz również ukrytego porozumienia wyrażającego rzeczywistą wolę stron. Umowa zawarta $\mathrm{z}$ pominięciem obowiązkowego trybu przewidzianego ustawą Prawo zamówień publicznych jest bowiem bezwzględnie nieważna ${ }^{14}$. Wskazaną tezę należy odnieść konsekwentnie również do umowy ukrytej pod pozorem innej czynności prawnej. Właściwość umowy zawieranej w ramach zamówień publicznych przeciwstawia się uznaniu za ważne wewnętrznego porozumienia dokonanego z pominięciem obowiązkowego trybu narzuconego przez przepisy ustawowe.

\subsection{Błąd}

Błąd jako wada oświadczenia woli może zaistnieć po stronie zarówno zamawiającego, jak i wykonawcy. Należy mieć jednak na uwadze, że o wskazanej wadliwości można mówić jedynie w przypadku spełnienia wszystkich przesłanek przewidzianych przez ustawodawcę. Błąd musi zatem dotyczyć treści czynności prawnej i być istotny. Biorąc pod uwagę, że w zakresie omawianej tematyki oświadczenia woli są składane innej osobie (nie są to oświadczenia niemające adresata), znaczenie ma również, czy do powstania bądź utrwalenia błędu przyczyniła się druga strona czynności. Ustawodawca wymaga bowiem w takim wypadku, żeby błąd był wywołany przez drugą stronę, był znany drugiej stronie bądź łatwy dla niej do zauważenia ${ }^{15}$. Nie ma natomiast znaczenia, czy kontrahentowi możemy przypisać winę lub złą wolę. Jak już sygnalizowano, wszystkie trzy przesłanki (związek z treścią czynności, istotność błędu, postawa kontrahenta) muszą zostać spełnione łącznie.

Poważne wątpliwości $\mathrm{w}$ doktrynie i orzecznictwie budzi znaczenie pierwszej z wymienionej przesłanek, czyli związku błędu z treścią czynności prawnej. W ocenie autora błąd dotyczy treści czynności, jeśli dotyka elementów wyznaczonych przez źródła treści stosunku prawnego wymienione w art. 56 k.c. (oświadczenie woli, przepisy prawne, zasady współżycia społecznego, ustalone zwyczaje), względnie dotyczy treści wzorca umownego, którym posłużyły się strony ${ }^{16}$. Według prezentowanego stanowiska $\mathrm{w}$ rachubę wchodzą nie tylko elementy o charakterze czysto

${ }^{14}$ Tak stwierdził SN w wyroku z dnia 13 września 2001 r., IV CKN 381/00, OSNC 2002, nr 6, poz. 75, Legalis nr 51142.

${ }^{15}$ Ograniczenie to nie ma zastosowania w przypadku czynności nieodpłatnych, co jednak z perspektywy prowadzonych rozważań ma mniejsze znaczenie.

${ }^{16}$ Szerzej na temat różnego rodzaju błędów M. Królikowski, wyd. cyt., s. 157-167. 
normatywnym (ściśle związane z prawami lub obowiązkami stron). Przykładowo strony mogą w treści umowy w dość dokładny sposób opisać przedmiot świadczenia czy przedstawić swoje własne kwalifikacje. Taki błąd będzie dotyczyć treści złożonego oświadczenia woli, a zatem i treści umowy.

Zgodnie z alternatywną (obecnie nieco już rzadziej reprezentowaną) koncepcją błąd musi dotyczyć ściśle treści złożonego oświadczenia woli, a zatem nie może dotykać elementów, do których strony nie odniosły się wprost w treści zawieranej umowy ${ }^{17}$. $Z$ kolei $w$ myśl jeszcze innego, silnie reprezentowanego zapatrywania: „o uznaniu błędu za błąd co do treści czynności prawnej decyduje jego związek strukturalny, wewnętrzny z treścią czynności, o którą chodzi (...). Związek ten jest dostatecznie ścisły, jeżeli błąd tak ingeruje w treść czynności prawnej, że wypacza jej sens faktyczny lub prawny"18. W ocenie autora pierwsza z przytoczonych alternatywnych koncepcji ujmuje analizowany wymóg zbyt wąsko, natomiast drugie ujęcie w istocie zaciera różnicę pomiędzy rozważaną przesłanką a przesłanką istotności błędu (o tym ostatnim wymogu jest mowa dalej). Niewątpliwie jednak tak nieprecyzyjne pojęcie, jak „błąd co do treści czynności prawnej”, budzi poważne problemy interpretacyjne i może być źródłem znacznej niepewności prawnej, co stanowi poważną wadę obowiązującej regulacji.

Z kolei wymóg istotności dotyczy związku pomiędzy istnieniem błędu a faktem złożenia oświadczenia woli. O błędzie istotnym mówi się wtedy, jeśli w razie jego nieistnienia strona nie złożyłaby oświadczenia woli określonej treści. Istotność może być oceniana z punktu widzenia obiektywnego oraz subiektywnego i oba ta aspekty muszą zostać zrealizowane dla spełnienia wskazanej przesłanki ${ }^{19}$. Błąd jest obiektywnie istotny, jeżeli nie miałby on znaczenia w kontekście dokonania czynności dla typowego, rozsądnie oceniającego sprawę uczestnika obrotu. Z kolei aspekt subiektywny uwzględnia sytuację i oczekiwania samej strony. Oczywiście oba aspekty powinny być weryfikowane na moment złożenia oświadczenia woli, a nie w odniesieniu do momentów późniejszych, szczególnie nie do tej chwili, w której niezadowolona strona zaczyna kwestionować skuteczność zawartej umowy.

Wywołanie błędu drugiej strony może nastąpić przede wszystkim przez udzielenie nieprawdziwej (także nieprecyzyjnej) informacji. Może to dotyczyć zarówno informacji zamieszczonych przez zamawiającego w treści ogłoszenia czy specyfikacji istotnych warunków zamówienia, informacji zawartych w ofercie, jak również dalszych informacji czy wyjaśnień przedstawianych w toku postępowania przetargowego - przed ostatecznym zawarciem umowy. Bez znaczenia jest przy tym, czy podmiot udzielający informacji działał w sposób umyślny, jak również czy dołożył należytej staranności w zakresie weryfikacji jej poprawności i prawdziwości; kwe-

${ }^{17}$ Por. B. Swaczyna, Umowne zniesienie wspótwłasności nieruchomości, Warszawa 2004, s. 141.

18 Por. B. Lewaszkiewicz-Petrykowska, [w:] Kodeks cywilny. Część ogólna. Komentarz, red. M. Pyziak-Szafnicka, Warszawa 2009, s. 890.

${ }_{19}$ Zob. jednak Z. Radwański, [w:] System prawa prywatnego. Prawo cywilne - czesść ogólna. Tom 2, red. Z. Radwański, Warszawa 2008, s. 401. 
stia winy jest tutaj pozbawiona znaczenia. Błąd może zostać wywołany również przez zaniechanie udzielenia informacji, o ile na danej osobie spoczywał obowiązek jej udostępnienia. Podstawą takiego obowiązku mogą być przede wszystkim przepisy prawne powszechnie obowiązujące (szczególnie przepisy ustawy Prawo zamówień publicznych, np. w zakresie obowiązku udzielenia wyjaśnień dotyczących wyliczenia zaoferowanej ceny lub kosztu - art. 90 p.z.p.).

Drugą stronę obciąża również sytuacja, w której dostrzegła błąd strony, jednakże nie zwróciła jej na to uwagi, jak również gdy błąd strony mogła łatwo zauważyć. Możliwość łatwego zauważenia błędu jest pojęciem nieostrym, trudnym do precyzyjnego określenia. Niemniej warto w tym miejscu zwrócić uwagę na art. 87 ust. 1 p.z.p. przewidujący możliwość żądania od wykonawców wyjaśnień dotyczących treści ofert. $Z$ kolei art. 87 ust. 2 p.z.p. nakłada na zamawiającego obowiązek poprawiania oczywistych omyłek pisarskich, rachunkowych czy innych omyłek polegających na niezgodności oferty ze specyfikacją istotnych warunków zamówienia, niepowodujących jednakże znacznych zmian $\mathrm{w}$ treści ofert ${ }^{20}$. Wskazane regulacje mogą dotyczyć sytuacji, w których błąd czy omyłka są widoczne dla zamawiającego bądź gdy treść oferty jasno wskazuje na istnienie takiego błędu. Warto jednak w tym miejscu zauważyć, że obowiązujące przepisy proceduralne w znacznym zakresie ograniczają możliwość zawarcia umowy obciążonej takimi niedokładnościami czy to przez wskazane mechanizmy związane z żądaniem wyjaśnień, poprawianiem omyłek czy też przez regulacje nakazujące odrzucenie oferty zawierającej błędy w obliczeniu ceny lub kosztu. Istnienie tych regulacji, przy założeniu ich prawidłowego stosowania, pozostawia zatem - jak się wydaje - niewiele miejsca na umowy obarczone błędem, który był znany zamawiającemu lub mógł być przez niego z łatwością zauważony.

\subsection{Podstęp}

Regulacja podstępu (art. 86 k.c.) przewiduje liberalizację przesłanek umożliwiających stronie uchylenie się od oświadczenia woli złożonego pod wpływem błędu, jeżeli błąd ten został wywołany podstępnie przez kontrahenta, a niekiedy również przez osobę trzecią ${ }^{21}$. Błąd zostaje wywołany podstępnie, jeśli kontrahent celowo wywołał w świadomości strony fałszywe wyobrażenie (bądź utwierdza ją w tym nieprawidłowym przekonaniu) po to, żeby strona złożyła oświadczenie woli o określonej treści. Podstęp osoby trzeciej jest przypisywany kontrahentowi, jeśli wiedział on o błędzie lub czynność prawna była nieodpłatna (ta ostatnia sytuacja nie dotyczy już jednak zamówień publicznych). Jako osoby trzeciej nie można traktować osoby pozostającej z kontrahentem w stosunku podległości służbowej, pracowniczej czy

\footnotetext{
${ }^{20}$ Zob. szerzej J.E. Nowicki, Prawo zamówień publicznych. Komentarz, Warszawa 2018, s. 710-734.

${ }^{21}$ Zgodnie $\mathrm{z}$ alternatywnym stanowiskiem podstęp jest $\mathrm{w}$ istocie odrębną od błędu wadą oświadczenia woli. Por. B. Lewaszkiewicz-Petrykowska, Wady oświadczenia woli w polskim prawie cywilnym, Warszawa 1973, s. 132.
} 
organizacyjnej. Osobą trzecią nie będzie zatem na przykład pracownik zamawiającego, nawet jeśli nie uczestniczy on bezpośrednio w samej procedurze przetargowej.

Błąd wywołany podstępem nie musi dotyczyć treści czynności prawnej, jak również nie musi być istotny (w aspekcie obiektywnym). Błąd taki musi być jednak subiektywnie istotny dla strony. Należy zatem rozważyć, czy strona, która chce ubezskutecznić umowę, w istocie złożyłaby oświadczenie woli o określonej treści, gdyby nie miał miejsca podstęp kontrahenta. Zasygnalizować należy, że niezależnie od możliwości uchylenia się od wadliwego oświadczenia podstęp - podobnie jak dalej omówiona groźba - może być źródłem odpowiedzialności odszkodowawczej $(\text { deliktowej) })^{22}$.

\subsection{Groźba}

Ustawodawca przyznaje stronie możliwość uchylenia się od oświadczenia złożonego pod wpływem groźby, zarówno pochodzącej od drugiej strony umowy, jak i od osoby trzeciej. Groźba musi być bezprawna oraz poważna, co oznacza, że strona mogła obawiać się jej realizacji. Zagrożone mogą być interesy zarówno osobiste, jak i majątkowe strony lub innej osoby (niekoniecznie spokrewnionej czy związanej ze stroną). W rachubę może wchodzić przykładowo zagrożenie podjęcia niekorzystnej dla strony decyzji w odrębnej sprawie administracyjnej czy (z punktu widzenia zamawiającego) pogróżki skierowane przeciwko członkowi komisji przetargowej lub jego rodzinie.

\subsection{Konsekwencje powstania wady oświadczenia woli - wzmianka}

Jeśli chodzi o skutki zaistnienia wad oświadczenia woli w postaci braku świadomości albo swobody oraz pozorności ustawodawca posługuję się sankcją bezwzględnej nieważności. Z kolei dalej wymienione wady umożliwiają stronie uchylenie się od skutków złożonego oświadczenia woli na drodze pozasądowej - przez złożenie pisemnego oświadczenia kontrahentowi w terminie roku od chwili wykrycia błędu bądź ustania stanu obawy (art. 88 k.c.). Do zwrotu świadczeń spełnionych na podstawie bezwzględnie nieważnych bądź unieważnionych umów zastosowanie znajdują przepisy o nienależnym świadczeniu (art. 410 k.c.).

\section{Zakończenie}

Dotychczasowe rozważania prowadzą do wniosku, zgodnie z którym przepisy o wadach oświadczenia woli znajdują zastosowanie również do umów zawieranych w trybie zamówień publicznych. Mamy w tym zakresie do czynienia z czynnościami prawnymi podlegającymi reżimowi Kodeksu cywilnego, a reguły szczególne

\footnotetext{
${ }^{22}$ Zagadnienie zbiegu regulacji wad oświadczenia woli oraz przepisów o odpowiedzialności deliktowej jest przedmiotem pewnych kontrowersji. Zob. szerzej M. Królikowski, wyd. cyt., s. 295-306.
} 
wprowadzone ustawą Prawo zamówień publicznych dotyczą głównie samego trybu wyboru wykonawcy i zawarcia umowy, a nie kwestii konstrukcyjnych dotyczących kształtu oraz doniosłości czynności prawnej. Podkreślić należy, że prawo zamówień publicznych nie wprowadza normy prawnej wyłączającej stosowanie przepisów o wadach oświadczenia woli, a regulacje szczegółowe dotyczące unieważnienia umowy dotyczą odmiennej problematyki. Należy jednak mieć na uwadze, że umowy zawierane w trybie zamówień publicznych mają pewien szczególny wymiar publicznoprawny, służąc (czasami jedynie pośrednio) realizacji celów o charakterze powszechnym. Nie można zatem postrzegać relacji pomiędzy stronami takiej umowy jedynie w kategoriach konfliktu interesów występującego pomiędzy uczestnikami gry rynkowej, realizującymi swoje indywidualistyczne interesy o wymiarze głównie ekonomicznym. Z tego powodu można postulować, żeby wykładnia przesłanek umożliwiających powołanie się na błąd jako wadę oświadczenia woli była raczej rygorystyczna i nie zezwalała na zbyt szerokie możliwości uchylenia się od podjętych zobowiązań. Należy mieć jednak również na uwadze, iż dalsze przypadki wadliwości obejmują bardzo poważne zakłócenia procesu decyzyjnego (art. 82 k.c.) albo charakteryzują się nieetycznym wpływem na złożenia oświadczenia przez drugą stronę (podstęp, groźba). W tych - rzadkich jak się wydaje - przypadkach nie byłoby zatem właściwe, żeby różnicować sposób stosowania odpowiednich przepisów kodeksu cywilnego z uwagi na tryb zawarcia umowy.

Niewątpliwie czynnikiem sprzyjającym eliminacji wad jest sformalizowany charakter postępowania o udzielenie zamówienia publicznego, który zapewnia przejrzystość co do warunków uczestnictwa w przetargu oraz daje możliwość starannego przygotowania treści składanej oferty. W tym kontekście postrzegać można także dalsze mechanizmy kontrolne w zakresie możliwości żądania wyjaśnień dotyczących treści oferty czy korygowania błędów zawartych w ofercie, unieważnienia postępowania (art. 93 p.z.p.), jak również regulacje przewidujące możliwość złożenia odwołania od niezgodnej z przepisami ustawy czynności zamawiającego podjętej w toku postępowania (art. 180 i n. p.z.p.). Nie bez znaczenia są także szerokie kompetencje przyznane Prezesowi Urzędu Zamówień Publicznych, który może wystąpić do sądu powszechnego o unieważnienie zawartej umowy w przypadku dokonania przez zamawiającego czynności lub zaniechania dokonania czynności z naruszeniem przepisu ustawy, które miało lub mogło mieć wpływ na wynik postępowania (art. 146 ust. 6 p.z.p.). Wykazanie zasadności takiego żądania może w praktyce okazać się o wiele łatwiejsze niż udowodnienie wszystkich przesłanek wady oświadczenia woli w przypadku zbiegu takich dwóch środków prawnych. Biorąc pod uwagę te wszelkie okoliczności, można zatem uznać, że zastosowanie przepisów kodeksu cywilnego o wadach oświadczenia woli do umów zawartych w trybie zamówień publicznych dotyczyć może sytuacji w istocie wyjątkowych. 


\section{Literatura}

Brzozowski A. (red.), System prawa prywatnego. Tom 6. Prawo zobowiąań - część ogólna, Warszawa 2018.

Dmowski S., Rudnicki S., Komentarz do kodeksu cywilnego. Księga pierwsza. Część ogólna, Warszawa 2009.

Gniewek E., Machnikowski P. (red.), Kodeks cywilny. Komentarz, Warszawa 2014.

Gniewek E., Machnikowski P. (red.), Kodeks cywilny. Komentarz, Warszawa 2017.

Granecki P., Prawo zamówień publicznych. Komentarz, Warszawa 2016.

Jaworska M., [w:] Prawo zamówień publicznych. Komentarz, Warszawa 2018.

Królikowski M., Błą jako wada oświadczenia woli strony umowy, Warszawa 2014.

Lewaszkiewicz-Petrykowska B., Wady oświadczenia woli w polskim prawie cywilnym, Warszawa 1973.

Machnikowski P., Swoboda umów wedlug art. $353^{I}$ KC. Konstrukcja prawna, Warszawa 2005.

Nowicki J.E., Prawo zamówień publicznych. Komentarz, Warszawa 2018.

Pyziak-Szafnicka M. (red.), Kodeks cywilny. Część ogólna. Komentarz, Warszawa 2009.

Radwański Z. (red.), System prawa prywatnego. Prawo cywilne - część ogólna. Tom 2, Warszawa 2008.

Swaczyna B., Umowne zniesienie wspótwłasności nieruchomości, Warszawa 2004. 